\title{
Sovyet Arşiv Belgeleri Işığında Basmacı Hareketi
}

\author{
Okan Yeşilott*- Burcu Özdemir**
}

\begin{abstract}
$\ddot{O}_{z}$
Basmacı hareketinin doğuşuna zemin hazırlayan gelişme, Geçici Hükümet döneminde teşkil edilen Hokand Muhtar Hükümeti’nin, 1918 yılında ortadan kaldırılması oldu. 1918 yılında hareket Fergana'ya da yayıldı. Bunu, Hive ve Buhara izledi. Basmacı gruplar, ayrı bölgelerde teşkil edilmiş birliklerdi. Her liderin kontrolü altında ayrı bir bölge bulunuyordu. Basmacı hareketin amacı, Türkistan'ı Sovyet hakimiyetinden kurtarmaktı. Hareket, 1921 yılında Enver Paşa'nın liderliğinde büyük bir ivme kazandı. Enver Paşa'nın 1922 yılında öldürülmesiyle Basmacı hareket sona ermedi ancak, ilk yıllardaki üstünlügünü yitirdi. 1926 yılında Lakay boyu lideri İbrahim Bek idaresinde Basmacı harekette yeniden bir canlanma meydana geldi. Fakat bu direniş de 1931 yılı Haziran'ında sonlandırıldı ve İbrahim Bek tutuklandı. Türkiye'de Basmacı hareketini ele alan çok sayıda çalışma mevcuttur. Bugüne kadar yapılan çalışmalarda Basmacı terimine, hareketin nasıl doğduğuna ve geliştiğine, hareketin başarısızlıkla sonuçlanma nedenlerine ve Sovyet iktidarının bu mücadelede kullandığı taktiklere yer verilmiştir. Bu çalışmada ise, Rusya Devlet Askeri Arşivi'ndeki (PГBA/ RGVA) belgelerden örneklerle mücadelenin bir de Sovyetlerin gözünden aktarılması hedeflenmiştir. Hareketin önemli liderlerinden İbrahim Bek'e ve halk tarafindan mitleştirilmesine dair bilgiler, sadece Sovyet yönetiminin değil Kızıl Ordu askerlerinin Basmacılarla mücadeleye dair görüşleri, Basmacılık hareketine Türkistan halkının desteğinin askeri yazışmalara yansımaları, Basmacılıkla mücadele amacıyla gayrı Rus birliklerin teşkili ve bu süreçte karşılaşılan zorluklar, Sovyet yönetiminin harekete halk desteğini ortadan kaldırmak için din adamlarından nasıl istifade ettiği gibi konular bunlardan bazılarıdır.
\end{abstract}

Anahtar Kelime: Basmacılık, Korbaşı hareketi, Türkistan, Kızıl Ordu

* Prof. Dr., Marmara Üniversitesi, Fen Edebiyat Fakültesi, Tarih Bölümü, İstanbul/TÜRKIYY, oyesilot@marmara.edu.tr ORCID: 0000-0002-0798-2364

** Dr., Manisa Celal Bayar Üniversitesi, Fen Edebiyat Fakültesi, Tarih Bölümü, Manisa/TÜRKIYE, ozdemirburcu85@gmail.com ORCID: 0000-0003-1352-018X

DOI:?????????????

Makale Gönderim Tarihi: 18.12.2019 - Makale Kabul Tarihi: 16.11.2020

Belleten, Nisan 2021, Cilt: 85/Sayı: 302; 279-309 


\title{
The Basmachi Movement in the Light of Soviet Archival Documents
}

\begin{abstract}
The emergence of the Basmachi movement is usually associated with the the abolition of the Kokand government in 1918. In 1918 the insurgency also began to spread to Fergana. This was followed by Hive and Bukhara. The Basmachi groups were units formed in separate regions. Each leader had a separate territory under his control. The goal of the Basmachi was to liberate Turkestan from Soviet rule. The movement was strengthened under the leadership of Enver Pasha in 1921. With the murder of Enver Pasha in 1922, the Basmachi movement did not end, but lost power of the previous years. Under the leadership of Ibrahim Bek, the Lokai tribal leader, Basmachi movement revived in 1926. However, this resistance was ended in June 1931 and Ibrahim Bek was arrested. There have been numerous studies on the Basmachi movement in Turkey. All studies to date, however, have included the term "Basmachi", the emergence and development of the movement, the causes of movement's failures and the Soviet tactics during the fight. Aims of this work was to explain the Basmachi movement through the eyes of the Soviets with archival documents in the Russian State Military Archive. These topics include the following: one of most prominent leaders of the movement, Ibrahim Bek and the mythologizing of his leadership by the people, not only Soviet administration but also views of Red Army soldiers on the struggle, reflections of Turkestan people's support for the movement on military correspondence, formation of non-Russian troops for struggle against the Basmachi and the problems of this struggle and how the Soviet administration used the clergy to eliminate popular support for the movement.
\end{abstract}

Keywords: Basmachi, Korbashi movement, Turkestan, the Red Army

\section{Giriş}

Basmacı hareketi üzerine yapılan mevcut araştırmalarda ortak tartı̧ma konularından birini, Türkistan'da Sovyet yönetimine yönelik bu başkaldırı hareketini hangi terimle ifade etmek gerektiği meselesi teşkil etmektedir. $\mathrm{Bu}$ bakımdan öncelikle, bu çalışmada neden Basmacı teriminin tercih edildiğini açı̆̆a kavuşturmak gerekmektedir. Bilindiği gibi, Basmacı terimi Sovyet literatürüne ait bir tanımlamadır ve 'baskın yapan', 'çeteci' manasına gelmektedir. Bu şekilde bir tanımlama, hem hareketin mahiyetini olumsuzlamakta hem de etkisini azımsamaktadır. Halbuki 1918-1935 yıllarını içine alan bu ayaklanma, Sovyet yönetimini Iç Savaş ylllarında en çok uğraştıran meselelerden biri olmuştur. 
$\mathrm{Bu}$ konudaki çalışmalarıyla tanınan Baymirza Hayit de eserlerinde Sovyet tarih biliminde bilinen adıyla "Basmacı" tabirini kullanmışır. Ancak Rusların kullandıkları anlamda kullanmadığını da özellikle belirtmiş̧ir ${ }^{1}$. Buna mukabil, hareketi Korbaşlar hareketi olarak da tanımlayan çalışmalar mevcuttur. Bu çalışma, Basmacı teriminin eksik ve hatalı bir tanımlama olduğunu kabul etmektedir. Ancak sadece Rus ve Batı literatüründe değil Türkiye'de de en yaygın ve bilindik tanımlama Basmacı terimi olduğundan böyle bir tercihte bulunulmuştur.

Basmacı hareketinin ortaya çıkısıı sistematik bir şekilde olmadı. Türkistan'ın belirli bölgelerinde ve farklı zaman dilimlerinde baş gösteren ayaklanmalar birbirinden kopuk bir şekilde gerçekleşti. Aynı şekilde hareketin sonlandırılması da yine farklı bölgelerde farklı tarihlerde meydana geldi. İklil Kurban, Basmacı hareketinin başlangıcı olarak Hokand Muhtar Hükümeti’nin devrilmesini, yani 1918 yllını kabul eder². Abdülkadir Donuk da hareketin, 1918'de Korbaşı Ergaş3 liderliğinde Hokand'ta başladığını ifade eder. Basmacılık hareketi üzerine yapılan son çalışmalardan birinde, yazar Altmışova, bazı araştırmacıların hareketi 1916'da Çarlık Rusya'sına karşı başlayan isyanın devamı olarak gördüğünü, buna mukabil çoğunluğun hareketin başlangıcı olarak 1918 yllında Hokand muhtariyetinin yıkılmasından sonrasını kabul ettiklerini belirtmiştir ${ }^{5}$. İklil Kurban da Basmacı hareketinin 1918 yllında Hokand Muhtar Hükümeti'nin dağıtılmasından sonra ortaya çıktığını söylemiştir ${ }^{6}$. Mevcut araştırmalarda hareketin bitiş tarihi konusunda da bir fikir birliğinin bulunmadığı görülmektedir. Örneğin Altmışova Basmacı hareketinin 1934 yllında sona erdiğini belirtir? ${ }^{7}$ Donuk ise, Rusların

1 Baymirza Hayit, "Basmacılar”: Türkistan Milli Mücadele Tarihi (1917-1934), Türkiye Diyanet Vakfi Yayınları, Ankara 1997, s. 1-2; Baymirza Hayit, Türkistan Devletlerinin Milli Mücadeleleri Tarihi, Türk Tarih Kurumu Basimevi, Ankara 2004, s. 275.

2 İklil Kurban, "Basmacılar", Selçuk Üniversitesi Türkiyat Araşttrmalan Dergisi, S. 4, Konya 1997, s. 128.

3 Korbaşı Ergaş: Milli mücadeleyi başlatarak harekatlar düzenleyen ilk özgürlük savaşçısı ve aynı zamanda özgürlük mücadelesi kıtalarının ilk baş kumandanıydı. Onun önderliğinde Hokand'da başlayan Basmacilık hareketi kısa zamanda diğer bölgelere de yayılmıştır. Onun hedefi Ruslardan arınmış, bağımsız bir devlet tahsis etmekti. Ergaş, 1921 ylına kadar savaşmaya devam etmiştir. Daha sonra esir düşmüş ve Sovyetler tarafindan idam edilmiştir. Baymirza Hayit, "Basmacılar": Türkistan Milli Mücadele Tarihi (1917-1934), Türkiye Diyanet Vakfi Yayınları, Ankara 1997.

4 Abdülkadir Donuk, "Basmacı Hareketi”, TDVA, G 5, İstanbul 1992, s. 107.

5 Zuhra Altımısova, "Kırgızistan'da Basmacı Hareketiyle İlgili Yeni Bilgiler (1925-1934)", Bilig, S. 82, Ankara 2017, s. 92.

6 Kurban, agm., s. 128.

7 Altmışova, agm., s. 93. 
Basmacılık hareketine 1935 yılında son verdiğini ifade eder $^{8}$. Bu çalışmada kullanılan Sovyet raporlarının 1935 yılını da hareketin içine aldığı gerçeği göz önünde bulundurulduğunda hareketin bitiş tarihi olarak 1935 yılını kabul etmek gerekmektedir.

Hareketin başlayış ve bitişinin sistematik olmayışı gibi, hareketin kendisi de bir bütünlük içerisinde değildi. Basmacı gruplar, belirli bölgelerde ayrı ayrı teşkil edilmiş birliklerdi. Her liderin kontrolü altında ayrı bir bölge bulunuyordu ve bu kişiler, kendi askerlerinin temininden ve hazırlanmasından sorumlu idiler. Korbaşılar, idaresi altındaki halktan askerleri için vergi topluyor ve erzak talep ediyordu ${ }^{9}$. Gümüş, tek bir merkezden yönetilmemekle birlikte Basmacı grupların hiyerarşik olarak belli bir düzenleri olduğunu belirtmiştir. Korbaşının komutasında bir kurmay heyeti, askeri eğitimciler ve süratli hareket tarzına sahip atlı birlikler şeklinde yapılanmışlardı. Ancak düzenli birlikler değillerdi, gelişmiş bir askeri teçhizata sahip değillerdi. Basmacı gruplar, Türkistan'daki zengin aydınlar ve halk tarafindan finanse edilmekteydi ${ }^{10}$.

Basmacı hareketinin hedefi, Türkistan'ı Bolşevik hakimiyetinden kurtarıp kendi milli devletlerini kurmaktı ${ }^{11}$. Zaten pek çok kaynakta Türkistanlıların bağımsızlık isteğinin Basmacı hareketine yol açtı̆̆ı görüşü hakimdir. Gutliyev, Sovyetlerin bölgeye ilgisinin başlıca sebebinin Türkistan'ın hem petrol hem de pamuk dokuma sanayi açısından zengin oluşuna bağlamaktadır ${ }^{12}$. Altmışova da benzer görüştedir. O da ayaklanmanın sebebinin Sovyet yönetiminin, Çarlık Rusya’sı gibi, sömürgeci bir siyaset izlemesi olduğunu ifade etmiştir:

"Büyük sanayi işletmeleri yanında özel mülklerin, toprakların müsaderesi, Bolşeviklerin yerel inanç ve geleneklere müdahalesi, Sovyet hükûmetinin Ekim Devrimi akabinde verdiği ulusların kendi kaderini tayin hakkı sözünün yerine getirilmemesi, tam tersine yerli ahalinin menfaatlerinin göz

8 Donuk, agm., s. 108.

9 Martha Olcott, "The Basmachi or Freemen's Revolt in Turkestan 1918-24”, Soviet Studies, C. 33, S.3, 1981, s. 363.

10 Musa Gümüş, “Türkistan’da Vatan Müdafaacıları: Korbaşılar Hareketi ve Enver Paşa”, Tarih Okulu Dergisi, S. XXIV, 2015, s. 660.

11 Hayit, "Basmacılar": Türkistan Milli Mücadele Tarihi (1917-1934), s. 4.

12 Gurbangeldi Gutliyev, “Türkistan’daki Basmacılık Hareketi (1918-1924) Üzerine Değerlendirmeler", Anadolu Kültürel Araştırmalar Dergisi, S. 1 (2), 2017, s. 88. 
ardı edilmesi, şovenizm siyaseti uygulanması, kendi haklarını arayan halkı Sovyetlerle mücadeleye yöneltmiştir ${ }^{13 "}$.

Nitekim Basmacılar, Sovyetlerin teşkil ettikleri kolektif çiftliklere (kolhoz) karşı da mücadele etmiştir. Altmışova, Basmacıların, devlete ait ambarları, kooperatif ve dükkanları yağmaladıklarını ve bu malların bir kısmını halka dağıttıklarını ifade etmiştiri ${ }^{14}$. Sovyetlerin sömürgeci politikaları konusunda Gümüş de benzer düşüncededir. Yazara göre, tarım arazilerinin büyük kısmının pamuk tarımı için kullanılmaya başlanmasıyla, Türkistan halkı başta buğday olmak üzere diğer ürünlerde Sovyet yönetimine bağımlı hale getirilmiştir. Bunun yanı sıra tarımda makineleşmenin de Türkistan halkını Rus traktörüne, benzine ve Rus makinistlere bağımlı kıldığını ifade eden yazar, bu durumun halkın Basmacılara katılmasında etkili olduğunu savunmuştur ${ }^{15}$. Gümüş, Basmacı hareketin bağımsızlık talebiyle ortaya çıktığını söylemekle birlikte, Türkistan’ın her bölgesinde aynı yoğunlukta olmadığını, ağılıklı olarak Fergana, Lakay, Buhara ve Hive'de gerçekleştiğini ifade etmiştir ${ }^{16}$. Basmacı hareketinin Sovyet yönetiminin politikalarına bir tepki mahiyetinde olduğunu savunan bir diğer isim, Olcott'tur. Olcott'a göre, Türkistan'daki muhalefet hareketinin bu kadar güçlü olmasının nedeni, Sovyet yönetiminin Türkistan'daki hakimiyetinin siyasi yönetimdeki değişiklikten daha fazlası olmasıydı. Bu, Müslüman bir toplumu yeniden yapılandırma girişimiydi: Orta Asya'daki Sovyet devri politik, ekonomik ve sosyal bir devrimdi. Bolşevikler, din adamlarna ait topraklar da dahil olmak üzere tüm arazilerin derhal kamulaştonlmasmn istedi; bu, geleneksel liderlerin gücünü tehdit eden bir durumdu. Taşkent'teki Sovyet makamlar, Kuran okullarm yasaklayan ve tüm şseriat mahkemelerini kapatan din karşıt politikalar uygulamaya koydu. Bu benzeri görülmemis eylemler, Orta Asya'nn en ılıml kesiminin bile tepkisini çekti ${ }^{17}$.

Basmacı hareketin güçlenmesinde bölgedeki boy ilişkilerinin de etkisi büyüktü. Bir boydan bir kişi Basmacı harekete katılığında ve çete lideri olduğunda akrabaları da Basmacilara katılırd1 ${ }^{18}$.

13 Altmışova, agm., s. 92.

14 Altmışova, agm., s. 102.

15 Gümüş, agm., s. 658.

16 Gümüs, agm., s. 660.

17 Olcott, agm., s. 352.

18 Altmışova, agm., s. 104.

Belleten, Nisan 2021, Cilt: 85/Sayı: 302; 279-309 
Sovyet yönetimi, Basmacılık hareketiyle sadece silahlı mücadele yürütmekle kalmamış ve hareketin etkisini azaltmak amacıyla farklı politikalar uygulamaya koymuştur. Bunlardan biri, yerel halktan gönüllü birlikler teşkil edilmesiydi. Penati, bu birliklerin, güçlü olduklarını düşündükleri tarafı destekleyen ve eski Basmacılardan müteşekkil savaşçılardan oluştuklarını ve 1926 yılında bir gönüllüye aylık 150 ruble ödendiğini belirtmiştir. Gönüllü birlikler hem Basmacıların hem de Müslüman din adamlarının tepkisine neden olmuştur ${ }^{19}$. Basmacılıkla mücadelede bir diğer taktik, Sovyet yönetiminin Basmacı harekete dahil olanlar için belirli zaman dilimlerinde genel af ilan etmesiydi. Penati, korbaşların genel aftan yararlanmak istediğinde yerel komiteler tarafindan belirlenen arabuluculara başvurmak zorunda olduklarını, buna mukabil bireysel savaşçıların (yiğitlerin) en yakın yetkili idareye gidip teslim olabildiklerini ifade etmiştir ${ }^{20}$.

Bir diğer politika da göç politikasıydı. Basmacıların dağlık bölgelerde etkili olması nedeniyle, dağlık bölgelerde yaşayan göçerler yerleşik hayata geçirilerek kasabaların kurulması planlanmıştır ${ }^{21}$. Dağlardan ovalara yapılan bu göçler rasseleniye olarak adlandırılıyordu. Penati, Sovyet tarihçiliğinde Kızıl Ordu garnizonlarının yakınlarındaki köylerde yaşayan halkın göç ettirilmesinin, bu köyleri Basmacı yağmalarından korumak olarak açıklandığını belirtmiştir. Penati, bu açıklamanın bazı bölgeler için geçerli olmakta birlikte, göç siyasetinin bir diğer hedefinin, Basmacıları yerel halkın desteğinden mahrum bırakmak olduğunu ve 1925 yllından itibaren uygulanan yeniden yerleşim (pereseleniye) siyasetinin amacının ise, Basmacı harekete destek verenleri cezalandırmak ve aralarındaki iletişimi engellemek olduğunu ifade etmiştir ${ }^{22}$.

Bilindiği gibi, Rusya Devlet Askerî Arşivi (PГВA/RGVA), Sosyo-politik Tarih Rusya Devlet Arşivi (РГАСПИ/RGASPI), Rusya Devlet Tarih Arşivi (РГИА/ RGIA), Rusya Federasyonu Diş Politika Arşivi (ABПPФ/AVPRF) ve Rusya Federasyonu Devlet Arşivi (ГAPФ/GARF) Rusya'daki arşivlerin en önemli olanlarıdır. Çalışmada kullanılan arşiv belgeleri, Rusya Devlet Askeri Arşivi’ne (PГBA/RGVA) ait belgelerdir. Arşiv, 1920 yılında Kızıl Ordu Arşivi olarak kurulmuştur ve buradaki belgeler, Basmacı hareketine dair Kızıl Ordu'nun

19 Beatrice Penati, "The Reconquest of East Bukhara: The Struggle Against the Basmachi as a Prelude to Sovietization", Central Asian Survey, C 26/S. 4, s. 523.

20 Penati, agm., s. 525.

21 Altmişova, agm., s. 107.

22 Penati, agm., s. 529.

Belleten, Nisan 2021, Cilt: 85/Sayı: 302; 279-309 
istihbarat belgelerini içermesi açısından oldukça önem taşımaktadır. Bilindiği gibi, Türkiye'de Basmacılar konusunda çok sayıda çalışma mevcuttur ve bugüne dek yapılan bu çalışmalar, hareketi başlangıç tarihinden sona erdiği tarihe kadar gerek genel gerekse de bölgesel düzeyde ele almaktadır. Bu çalışmanın amacı, Basmacı hareketini bugüne dek bilinmeyen yönleri ile bir de Sovyet yönetiminin gözünden aktarmaya çalışmak olmuştur. Bu nedenle arşiv belgelerinin kullanımında bölgesel veyahut dönemsel bir ayrıma gidilmemiş, çalışmanın başlıca hedefi, Basmacı hareketine dair bugüne dek bilinmeyen bilgileri içermesi ve bu bilgilerin elbette bir konu bütünlüğü içerisinde verilmeye çalışılması olmuştur.

\section{Basmacı Hareketinin Ortaya Çıkışı ve Akıbeti}

Basmacı hareketinin doğuşuna zemin hazırlayan gelişme, Geçici Hükümet döneminde teşkil edilen Hokand Muhtar Hükümeti’nin 1918 yılında ortadan kaldırılması olmuştur. Bu bakımdan bu gelişmeleri özetlemek yerinde olacaktır. Geçici Hükümet döneminde Türkistan'da birkaç müstakil sosyalist cumhuriyet kurulmuştu. Bununla birlikte, Geçici Hükümet’in yetkisi, çoğu Rus ve Türkistanlı tarafindan kabul edilmişti. Bölgede iki etkili grup, Cedidçiler ve ulema grubu idi. Bu iki grup, 13 Aralık 1917'de Ittifakul Müslimin (Müslüman Birliği) çatısı altında bir araya gelmiş ve Hokand Muhtar Hükümeti’nin kurulduğunu ilan etmiştir. Başlangıçta Sovyet yönetimi, bu hükümeti, kendi kaderini tayin etme hakkının bir ifadesi olarak kabul etmiştir ${ }^{23}$. 18 Ocak 1918'de Bolşevikler, Beyaz Ordu komutanlarından General Dutav denetimindeki Orenburg'u aldığında Taşkent-Moskova demiryolu hattını ele geçirmiş ve Taşkent'teki Kızıl Ordu'ya silah ve cephane yardımında bulunabilmiştir ${ }^{24}$. Böylece Türkistan'da gücünü arttıran Sovyet yönetimi, kurulduktan iki ay sonra Hokand Muhtar Hükümeti'ni dağıtmıştır ${ }^{25}$.

İklil Kurban, Hokand Muhtar Hükümeti'nin kurulmasını ve dağıtılmasını, böylelikle Basmacı hareketinin doğuş sürecini şöyle izah eder:

"Şir Mehmet Bek 17.08.1917 günü diye tahmin edilen tarihte, Gerbaba civarındaki 7 köyün ileri gelenlerini Gerbaba köyüne davet ederek, Ruslara karşı bir milli mücadele hareketini başlatmak niyetinde olduklarını beyan ile

23 Olcott, agm., s. 354.

24 Ali Bademci, 1917-1934 Türkistan Milli İstiklal Hareketi, Korbaşzlar ve Enver Paşa, Ötüken Neşriyat, İstanbul 2008, s. 150.

25 Kurban, agm., s. 128. 
yardım talebinde bulunur. 7 köyün imamı hemen çevreyi dolaşarak yardım toplayacaklarını bildirirler. Şir Mehmet Bek'in örgütlenmesi, hakimiyet kurması işte böyle imamlar eşliğinde başlar. Hokand Muhtariyet Hükümeti kurulurken, Mehmet Emin Bek bu hükümetin milis kuvvetleri terkibinde yer alır. Hükümet dağıtılınca, Mehmet Emin Bek yakın silah arkadaşlarıyla beraber ilk karargahını Gerbaba köyünde kurar.”... Çevreden gelen çiftçi delikanlılar burada askeri eğitim görür. 1918 yılının bütün yazı burada, Mehmet Emin Bek çevresinde toplanan insanların silahlanması, büyümesi devam eder. Bu işe, Beyaz Rus subayları ile Afgan mücahitlerinin büyük katkisi olur ${ }^{26} "$.

1918 yılında hareket Fergana'ya da yayılmıştır ${ }^{27}$. Fergana'daki tüm bölge ve mıntıka kumandanları, Şir Mehmet Bek'in ${ }^{28}$ Gerbaba'da çekirdeğini teşkil ettiği birliğe tabi olmuştur ${ }^{29}$. Hokand ve Fergana'yı, Sovyet hakimiyeti altına girdikten sonra Hive ve Buhara izlemiştir. Bolşevikler ilk iki yıl, Basmacı hareketi üzerine yeterince yoğunlaşamamıştır. Bunun nedeni, daha büyük bir tehdit olarak gördükleri Beyaz Ordu'nun saldırıları olmuştur. Böylece Basmacı hareketiyle mücadele, Türkistan'daki yerel yetkililere bırakılmışıır ${ }^{30}$. Bu ilk yıllarda Basmacı hareket, merkezî olmaktan uzaktır. Olcott, çeşitli grupların temas halinde olduklarını, ortaklaşa saldırılar düzenlediklerini ancak hangi komutanın lider olduğu konusunda bir anlaşmazlığın mevcut olduğunu ifade etmiştir. Basmacı komutanlarından Ergaş, bu sorunu çözüme kavuşturmak amacıyla, Mart 1919'da 40 kadar Basmacı liderini toplantıya çağırmıştır. Toplantı, Ergaş'ı komutan ve

26 Kurban, age., s. 131.

27 Donuk, agm., s. 107.

28 Şir Mehmet Bek (1893-1970): Fergana vadisinin Gerbaba köyünde doğmuştur. 1916 yllında Rus Çarlı̆̆’’nın fermanı ile çalıştırılmak üzere Polonya'ya gönderilmiştir. 1917 yılında Fergana'ya döndükten sonra Rus askerlerinin bölge halkına yaptığı baskılara şahit olduktan sonra bölgedeki gelişen hareketlerde aktif şekilde rol almıştır. Ilk başarısı 8 Eylül 1917'de Ekberabad kasabasındaki kooperatifi ele geçirmesidir. Ruslar karşısındaki zaferleri onun kısa zamanda Fergana'da tanınmasını sağlamıştır. Lider Mehmet Emin Bek’in 1920 yılında öldürülmesinden sonra onun yerine geçmiştir. Bu vazife ile Gerbaba köyünde bir kurultay düzenleyerek 3 Mayıs 1920 tarihinde Türkistan Müstakil Hükümeti'ni kurmuştur ve tam muhtariyet alınana kadar mücadelesine devam edeceğini bildirmiş̧ir. Onun kurduğu hükümet Türkistan Milli Birliği ile temas halinde olmuştur. 1921 yılında ard arda aldığı mağlubiyetler sonucunda önce Buahara'ya sonra da Afganistan'a kaçmak zorunda kalmıştır. 1955 yllında Türkiye'ye gelerek Adana'ya yerleşmiş ve hayatının geri kalanına burada devam etmiştir. Emin Yarımoğlu, Korbaşı Türkistan Milli İstiklal Hareketi Liderlerinden Şir Muhammed Bek, Bozkurt Yayınları, İstanbul 2019.

29 Bademci, age., s. 191.

30 Olcott, agm., s. 356.

Belleten, Nisan 2021, Gilt: 85/Say1: 302; 279-309 
Kurşirmat ile Madamin Bek'i onun iki vekili olarak tayin etmiştir. 40 Basmacı liderinin her birine savunmaları ve yönetmeleri için ayrı bölgeler verilmiştii ${ }^{31}$.

Sovyet yönetimi, Mayıs 1919'da Beyaz Ordu komutanlarından Kolçak'in yenilmesinden sonra Basmacı hareketini ortadan kaldırmak için önemli adımlar atmıştır. Bunlardan ilki, 13 Ağustos 1919 tarihinde Frunze komutasında Türkistan cephesinin kurulması ve 1., 4., 9. ve 11 . orduların bölgeye sevk edilmesi olmuştur ${ }^{32}$. Bir diğer önemli adım ise, Ekim 1919'da Taşkent'e Türkistan Komisyonu'nun gönderilmesi olmuştur. Komisyonun görevi, Basmacı isyanının nedenlerinin ve halk desteğinin sebeplerinin öğrenilmesiydi.

Kızıl Ordu birliklerinin bölgeye gelişiyle, Basmacı hareketinin seyri olumsuz yönde değişti. 4 Şubat 1920'de gerçekleştirilen saldırıda Mehmet Emin Bek yenildi ve Ruslarla barış yapmak zorunda kaldı. Ancak bu anlaşma, onun hainlikle itham edilerek öldürülmesine neden oldu ${ }^{33}$. Onun teşkil ettiğgi Fergana hükümeti, 7 Mart 1920'de Sovyetler tarafindan dağıtıldı ${ }^{34}$. Basmacı komutanlarından Madamin, Mayıs 1920'de öldü. Onun ölümünden sonra hareketin başına Kurşirmat geçti. Olcott, 1920 yllının sonunda Basmacıların, yerel halkla daha kolay iletişim kurabildikleri küçük kasabalara ve dağ yerleşimlerine sürüldüğünü belirtmiştir ${ }^{35}$.

Sovyet yönetimi, Türkistan Komisyonu'nun yaptığı soruşturmanın sonucunda Taşkent Sovyet'ini dağıtma ve Rus ve Türkistanlı Bolşevik destekçilerinden oluşan geçici bir Merkez Komitesi kurmaya karar verdi. Komisyonun üzerinde durduğu meselelerden biri, İç Savaş ylllarında meydana gelen kıtlığın sona erdirilmesiydi. Bu amaçla, Türkistan'a tahıl sevk edildi. Türkistan Komünist Partisi, Ağustos 1921'de teslim olan Basmacılar için genel af ilan edileceğini ve yeni ele geçirilen topraklardan çiftlik verileceğini duyurdu. Tomsky- Politbüro ve Türkistan Konisyonu üyesiydi- Türkistan halkının Bolşevikleri hem İslam'ın hem de geleneksel yaşamın bir düşmanı gibi gördüklerini ve din konusunda geçici bir taviz verilmesi gerektiğini savundu. Böylece Ekim 1921'de şeriat mahkemeleri yeniden faaliyet göstermeye başladı ${ }^{36}$.

31 Olcott, agm, s. 355.

32 Gümüş, agm., s. 664.

33 Gümüş, agm., s. 665.

34 Donuk, agm., s. 108.

35 Olcott, agm., s. 356.

36 Olcott, agm., s. 357. 
Hareket, 1921 yılında Enver Paşa'nın liderliğinde ivme kazandı. Enver Paşa, 1921 yılının sonlarından 1922 yılının Şubat ayına kadar 20.000'den fazla silahlı askeri etrafinda toplamayı başard ${ }^{37}$. Enver'in idaresi altında Basmacılar, Buhara'nın büyük kısmını yeniden ele geçirdiler. Ayrıca bu dönemde hareket daha merkezi bir hale geldi; Hive, Buhara ve Fergana liderleri arasında düzenli toplantılar gerçekleştirildi ${ }^{38}$.

Sovyet yönetimi bu süreçte ciddi kayıplar verdi, ancak toparlanmakta gecikmedi ve 1922 yılında karşı saldırıya geçti. Geçici Türkistan hükümeti dağıtıldı ${ }^{39}$. Aynı sene Enver Paşa’nın öldürülmesiyle Basmacı hareket zayıfladı. Olcott, şayet Enver Paşa öldürülmeseydi, onun Bolşeviklerin Türkistan’a yönelik planlarını bozacağını belirtmiştir ${ }^{40}$. Donuk da Enver Paşa'nın ölümüyle Basmacılığın birinci etabının sona erdiğini, 1924 yılında başlayan ve 1935 yılına dek devam edecek olan ikinci etapta Basmacı mücadelenin silah buldukça devam ettiğini ifade etmiştir ${ }^{41}$. Aynı bilgi, Altmışova tarafindan da teyit edilmiştir. Altmışova, bu ikinci evrede hareketin, dağınık şekilde ve küçük gruplar halinde 1934 yılına kadar devam ettiğini belirtmiştir ${ }^{42}$.

Enver Paşa'nın 1922 yılında öldürülmesiyle Basmacı hareket sona ermemişti ancak ilk yıllardaki üstünlügünü ve merkezi vasfinı yitirmişti. Olcott, 1922 yılının sonlarında Fergana'daki tüm büyük Basmacı liderlerinin öldürüldüğünü, yakalandığını veyahut saklanmak zorunda kaldıklarını ifade etmiştir. 1923 baharında Sovyet yönetiminin asayişi büyük oranda sağladı̆̆ını belirten Olcott, Sovyet makamlarının arazi dağıtımına başladıklarını ve pamuk ekonomisini yeniden canlandırdıklarını ve bunun Basmacıların yiyecek elde etmelerini zorlaştırdığını belirtmiştir ${ }^{43}$. Bununla birlikte, Enver Paşa'nın ardından direniş dağınık şekilde de olsa devam etmiştir.

1926 yılında Lakay boyu lideri İbrahim Bek idaresinde Basmacı harekette yeniden bir canlanma meydana gelmiştir ${ }^{44}$. Bunun üzerine Sovyet yönetimi, 1926 yılında

37 Hayit, "Basmacılar": Türkistan Milli Mücadele Tarihi (1917-1934), s. 204.

38 Olcott, agm., s. 359.

39 Donuk, agm., s. 108.

40 Olcott, agm., s. 359.

41 Donuk, agm., s. 108.

42 Altmışova, agm., s. 96.

43 Olcott, agm., s. 360.

44 Olcott, agm., s. 360.

Belleten, Nisan 2021, Gilt: 85/Say1: 302; 279-309 
Basmacılıkla mücadele için, "Türkistan cephesi” yerine "Orta Asya Askeri Devrim Konseyi'ni” (SAVO) teşkil etmiştir. Gümüş, bundan sonra Sovyetlerin Basmacılarla mücadelesinin şiddetlendiğini ifade etmiştir ${ }^{45} .1927$ yılında Sovyet yönetimi vakıf arazilerinin miktarını azaltmış, Eylül ayında ise şeriat mahkemeleri kapatılmış ve kolektifleştirme süreci başlamıştır. Bu durum, yeni bir Basmacı direnişini tetiklemiştir. İbrahim Bek ve Cüneyt Han, direnişi organize etmişler, ancak 1931 yılı Haziran'ında direniş sonlandırılmış ve İbrahim Bek tutuklanmıştır ${ }^{46}$. İçerisinde liderlerin de bulunduğu çok sayıda Basmacı, 192 1-1935 yılları arasında Türkistan'ı terk etmiştir. Onlar, Afganistan başta olmak üzere İran ve Çin hakimiyetinde olan Doğu Türkistan'a sığınmıştır ${ }^{47}$.

\section{Sovyet Arşiv Belgelerinde Basmacı Hareketi}

Basmacı hareketi, Sovyetlerin askeri alanda sahip olduğu teçhizat üstünlüğüne rağmen, iktidarı oldukça uğraştırmış ve hareketin bastırılması uzun yıllar sürmüştür. Hareketin en şiddetli olduğu yıllar, 1920'li yılların ilk yarısı olmuştur. Bu yıllara ait Sovyet istihbarat raporlarından 09.06.1921 tarihli belgede bölge bölge Basmacı hareketin ve Kızıl Ordu'nun vaziyeti hakkında bilgiler yer almaktadır:

"Yedisu bölgesi

Politik durum ve askeri birliklerin durumu genel olarak tatmin edici. Ekonomik durum diğer bölgelere kıyasla daha iyi. Vergiler için hazırlık çalışmaları gerçekleştiriliyor. Bununla birlikte, operasyon birlikleri gıda ve yem sıkıntısı çekiyor. Operasyonun başarısızlı̆̆ının ana nedenleri, askerlerimizin az sayıda olması, Sibirya birliklerinin zamansız harekete geçmesi, askeri istihbaratın yetersiz oluşu ve düşmanın tüm askeri birlikleri zayıflatmış olmasıdır. Birliklerimiz 3 Haziran'da ağır bir kayıp ve yenilgi yaşadı. İlerleme askıya alındı, 2. Bölüğün Askeri Kumandanlığı operasyona mevcut askeri birliklerle devam edilmesi halinde başarısız olunacağını ifade ediyor. Kızıl Ordu'nun Çin vilayetleri ve halkıyla ilişkileri gayet iyi. $\mathrm{Bu}$ vilayetler, Sincan ilinin tüm büyük merkezlerinin Beyazlar tarafindan ele geçirilmesinden endişe duyuyor. ... Ekim kampanyası tüm bölgelerde başarılı şekilde gerçekleştirildi.

Semerkand bölgesi

Bölgedeki siyasi durum son zamanlarda kötüleşti, özellikle Basmacıların aktif oldukları doğu Ura-Tyubinsk (Tacikistan) bölgesinde. Parti güçleri

45 Gümüs, agm., s. 667.

46 Olcott, agm., s. 361.

47 Hayit, "Basmaclar": Türkistan Milli Mücadele Tarihi (1917-1934), s. 5. 
harekete geçirildi ve tasfiye için önlemler alındı. Ekonomik durum genel olarak aynı.

\section{Trans-Hazar bölgesi}

Politik durumda genel bir değişiklik yok, vaziyet tatmin edici. İşçilerin ve demiryolu çalışanlarının durumu iyi. ... Çetecilik son yıllarda zayıflıyor, sadece tek tük vakalar var. İran sınırında silahlı çatışmalar devam ediyor. İran sınırında yeniden veba hastalıkları -Krasnovodsk'ta tifo- gözlemleniyor. Önlemler alındı, sağlık ekipleri çalışıyor.

\section{Fergana}

Fergana hala en problemli bölgelerden biri. Bölgenin Oş, Andican, Margilan, bazen Fergana gibi şehir merkezlerine Basmacıların saldırıları devam ediyor. ... Operasyon alanlarındaki askeri birlikler uygun yükseklikte konuşlanmadıklarından başarılı faaliyet gösteremiyorlar. Nüfusun politik durumu genellikle aynı, köy yönetim kurullarının çoğunluğunun çetecilerin etkisi altında faaliyet gösterdiğini kaydetmek gereklidir. Köylüler Sovyet gücü konusunda bulanık bir görüşe sahip. Sulyuktin (Kırgızistan) madenlerinde Basmacılar tarafindan kullanılan alanlarda endişe söz konusu. İşçilerin silahlarla Basmacılar yanında yer aldığı birkaç vaka meydana geldi, Celalabad'taki kulak köylerinin silahsızlandırılması için çalışmalar yürütülüyor, bu nedenle yoksulların ruh hali önemli ölçüde kötü. Basmacılar yüzünden bölgenin genel vaziyeti gergin olduğundan, bölge halkı ekonomi ve politikayla yeterince ilgilenmiyor, nitekim kooperatiflerdeki seçimlere 1000 vatandaştan sadece 10 'u katıldı.

\section{Sir-Derya}

Fergana'da olduğu gibi, Tarım Yürütme Komitelerinde de kulaklar güçlü bir etkiye sahip. Bu yüzden Taşkent'in bazı köylerinde Tarım Yürütme Komiteleri tasfiye edilerek yerine geçici olarak Devrimci Komiteler görevlendirildi. Son zamanlarda Ablık (Angren/Taşkent) bölgesinde Basmacı hareket yeniden canlandı. Fergana'dan gelen toplam 700 kişi ile yeni çeteler kuruldu. Ablık'taki birliğimize saldırı hazırlığı yapıldığı bilgisi var. Ablık birliğindeki disiplinin gevşemesine rağmen halk, genel olarak Kızll Ordu'ya sempati duyuyor ${ }^{48 "}$.

Bu rapordan 12 gün sonra ve "çok gizli" ibaresiyle gönderilen bir başka raporda ise, Basmacı hareketin durumuyla ilgili şu açıklamalar yer almaktadır:

"Çok gizli

Sir-Derya

Ablık (Angren/Taşkent) halkının bir kısmı, Basmacılara katılan Ablık birliğine yardımda bulunuyor. Buna karşılık birliklerimizin gevşek ve 
kararsız hareketleri rahatsızlık verici. Basmacılara karşı daha başarılı bir askeri operasyonun geliştirilmesi, özellikle asker sayımızın yetersiz olması nedeniyle mümkün değildir.

Taşkent'te çeteler baskınlar gerçekleştiriyorlar. Doğrulanmamış verilere göre, Urazbek Kulkarev'in komutası altındaki Basmacıların 100 kadarı kalibreli tüfeklerle donatılmış durumdadır. Takviye askeri birlik sevk edildi. Ayrıca, Taşkent'ten istihbaratçlar da bölgeye gönderildi.

Semerkand

Askeri üniformalar yetersizdir. Bazı Kızıl Ordu askerlerinin giysisi yok. Aralarında tifoya yakalananlar var. ... Basmacı hareketine yönelik planlanan gelecekteki operasyonlar için tabur, acilen muharebe kabiliyetini arttırmalıdır. ... Basmacılık hareketi yatışmış vaziyettedir, hareket özellikle Uratyubinsk bölgesinde kendisi gösteriyor. ... Kattagan'da Basmacılarla mücadele başarılı gidiyor. Baskı altına aldığımız Basmacılar saldırıyor ve Buhara topraklarına kaçıyor. Bizim tahkikat birimimizin çalışamadığı yerlerde Buhara birlikleri anlaşma önerdi. Bu bölgede faaliyette bulunan Basmacılar panik halindeler. Sayıları tam olarak bilinmeyen Cizzak'taki Basmacılar, Semerkant tarafina yöneldiler; onları karşılamak için Çeka görevlileri yönlendirildi ${ }^{49}$ ".

17.08.1921 tarihine ait bir diğer raporda da durumun, özellikle Fergana bölgesinde, Sovyet yönetimi açısından ne derece vahim bir hal aldığı açıkça görülmektedir:

Vergiler toplanmaya başlandı ancak Basmacılık yüzünden ilk neticeler iyi değil. ... Birçok yerde köy yöneticilerini ve vergi toplayıcılarını Basmacılar tayin ediyor, Oş’ta vergiler sadece Basmacılar tarafindan toplanıyor. Erzak grubu faaliyete başladı. Celalabad bölgesinde terk edilmiş tarlalardaki hasat çalışmaları için sendika üyelerinin \%10’u seferber edildi. Korbaşı Yuldan, OOzkent'teki polis biriminine düzenlediği saldırıda 22 adet tüfek ve 500 mermi ele geçirdi. Sovyet yönetimi tarafina geçen Korbaşı Alnar, barış görüşmelerinde bulunmak için Kurşirmat'a gitti. ... Fergana grubu askeri birimlerinin durumu tatmin edici değil ve siyasi çalışmalar hala zayıf durumda ${ }^{50}$.

Basmacı hareketin bu ilk dönemlerinde, Buhara Komünist Partisi Merkez Komitesi üyelerinden Mavlyanbekov'un ve Pozdnışev’in, Türkistan Cephesi Askeri Devrim Konseyi üyesi Berzin'e 11 Şubat 1924 tarihinde yazmış oldukları "Basmacılık Hareketinin Nedenleri" başlıklı rapordan, Sovyet yetkililerinin meseleye nasıl

49 RGVA, f.110, op.1, d.139, 1.16ob, 17, 17ob.

50 RGVA, f.110, op.1, d.139, 1.39. 
ciddiyetle eğildiği ve hareketin sebepleri konusunda bir anlaşmazlık içerisinde oldukları anlaşılmaktadır:

"Buhara'daki Sovyet okullarının sayısının az oluşunun, Basmacı hareketinin uzamasının nedenlerinden biri olduğu şeklindeki fikrinize katılmıyoruz. $\mathrm{Bu}$ iddianız, ülkenin mevcut durumuyla kesinlikle örtüşmemekte. Ayrıca raporunuzda yerel dini özelliklerinden bahsediyorsunuz. Bunlar, yeni Sovyet okullarının bugünkü yapısında çok ciddi engellerdir. Tepeden tırnağa dini afyonla zehirlenen köylü halkın çoğunluğu tarafindan Sovyet okullarının aşırı ve gayretli bir şekilde yaygınlaştırılması, dine karşı bir sefer olarak değerlendirilebilir. Bu nedenle, okulların inşası meselesinde çok dikkatli olunmalı... E Ĕger bu fenomeni ortadan kaldırabilirsek ve askeri birliklerin gerektiği şekilde ikmal edilmesini sağlayabilirsek, o zaman Basmacılıkla olan mücadelede ilerleriz.... Aynı zamanda Buhara halkının henüz Emir yönetimi ile Sovyet yönetimi arasında maddi açıdan önemli bir fark hissetmediği şeklindeki açıklamanıza da itiraz ediyoruz. Bu açıklamayı tamamen mantıksız ve genel bir ifade olarak görüyoruz ${ }^{51}$ ".

Kuşkusuz, Basmacı hareketin bu denli güçlenmesinde bölge halkının desteğinin de önemi büyüktü. Türkistan halkının büyük kısmı, Basmacılara destek vermekteydi. Arşiv belgelerindeki örneklerden anlaşıldığına göre, bu desteğin büyümesinde, Sovyet iktidarının hatalı yönetiminin de payı mevcuttu. Nitekim mücadelenin ilk yıllarına ait belgelerden birinde, Basmacılara halk desteğinin artmasında Sovyet yönetiminin toprak reformunun da etkisinin olduğu anlaşılmaktadır: "Türkistan Kafkasya tümeni komutanı, Nikolsk köyü sakinlerinden, Korbaşı İsrafil'in köylülerin Basmacılar tarafina geçmeleri önerisinde bulunduğu bilgisini aldı, toprak reformu nedeniyle köylülerden bazıları Basmacılara geçmek düşüncesindeler.... Türkistan Cephesi Komutanlığı, Nikolsk köylülerinin Basmacılar tarafina geçişinin engellenmesi için gerekli tüm tedbirleri almamızı ve alınan tüm tedbirlerin rapor edilmesini emretti" ${ }^{\prime 52}$. Toprak reformunun yanı sıra Sovyet aparatının zayıflı̆̆ ve özellikle ekonomik problemler, Basmacılara olan halk desteğinin artışında etkili olmuştur. Öyle ki, bu durum askeri yazışmalara da yansımıştır. Örneğin, 13 Temmuz 1931 tarihinde Yan Borisoviç Gamarnik'le yapılan bir yazışmada Basmacılara ciddi bir halk desteğinin olduğundan bahsedilmiştir:

"Saygıdeğer Yan Borisoviç

2 aydır, Basmacı liderlerinin -en yetkilisi İbrahim Bek'ti- Afganistan'dan gerçekleştirdiği saldırıların neden olduğu Tacikistan ve Özbekistan'daki

51 RGVA,f.110,op.1,d.226,1.21.

52 RGVA,f. 110,op.1,d.139,1.31.

Belleten, Nisan 2021, Gilt: 85/Say1: 302; 279-309 
Basmacı hareketi ortadan kaldırmak için bölgenin bir kısmında yoğun, gergin bir mücadele sürüyordu. Tacikistan'daki durum, son derece ağırdı ve hükümetin ve Merkez Komite'nin değerlendirmesine göre, genel bir ayaklanma yakındı. Bölgede feodal-kabile ilişkilerinin, feodal grupların, din adamları ve memurlar zümresinin yarattığı muazzam boyutta bir ekonomik ve politik gerilik söz konusuydu. Tüketim malları ve ekmek ikmalinde büyük bir problem mevcuttu. Bölgede aşırı zayıflık, tıkanıklık gibi sorunlara ve hatta, çoğu zaman, taban Sovyet aparatının bize karşı düşmanca tutumuna karşılık, Basmacılık hareketine karşı bir sempatizanlık ve hatta harekete doğrudan aktif bir katılım söz konusudur" ${ }^{\prime 53}$.

"Basmacılarla Mücadele Bölgelerindeki Ekonomik Durum Hakkında" başlıklı bir diğer belgede, Basmacılara halk desteğinin artışında bölgedeki kıtlı̆̆ın da etkisi olduğu ifade edilmiştir:

"Kurgan Tepe (Tacikistan) rayonundaki bazı yerlerde, ekmek ve mal tedarikinde yaşanan aksaklıklar nedeniyle kasvetli bir ruh hali mevcut. Vahş ve Dangara kolhozlarında da işçilerin çalışmaması nedeniyle tedarik konusunda aksamalar söz konusu. Kurgan Tepe ve Aral'da ciddi bir yiyecek kıtlığı var. Kızıl Mazar (Özbekistan)'da da ciddi oranda yiyeceğe ihtiyaç var. ... Fergana Vadisi'nin Özbek kısmında göçmenler, göçmen bürolarına hoşnutsuzluklarını dile getiriyorlar, aylardır buraya yardım gitmiyor, göçmenler ekmeğin pud'unu 40 rubleye satın alıyorlar, vatanlarına geri dönmeyi düşünüyorlar. ... Aşkabad'ta tarlalar çekirge istilasına uğradı, merkezden yardım gelmedi, sanayi ürünlerine büyük ihtiyaç var.... Yeni Pazar bölgesinde Basmacı harekette önemli bir canlanma söz konusu. Bölgedeki ciddi erzak sıkıntısı nedeniyle, halk arasında Basmacı hareket gelişiyor $^{54 "}$.

Basmacı harekete halk desteği konusunda Kızıl Ordu askerlerinin görüşleri bilhassa dikkat çekicidir. Kızıl Ordu askerlerine göre, Basmacı hareketine halk desteğinin büyümesinin nedeni, Sovyet yönetimi ve Parti’nin yanlış politikalarıdır. 1931 yılına ait bir belgede, Tacikistan'da görev yapan Kızıl Ordu askerilerinin bu konudaki görüşleri yer almıştır:

"Bizi yerel halka karşı güler yüzlü davranmaya zorluyorlar; ama böyle bir politika sadece bize yönelik değil, onu uygulayabildikleri herkese yönelik. Bu politika sürekli mücadele ettiğimiz haydutluğa yol açıyor. Ĕğer burada sert bir politika uygulasaydık, böyle bir şey olmazdı. Halk arasında çevresel bir güvenlik oluşturmamız gerekli, eğer bir dehkan bile Basmacılara 
katılırsa bütün köy yok edilmeli. Böyle olursa Basmacı hareketi başarılı olamayacaktır. -Smurugin, orta sinıf köylü-

... Din adamları ve yetkililer yok edilmeli ve halka savaşta olduğumuz gösterilmelidir, bu taktirde tüm halk bizi takip edecektir. ... Sovyet iktidarının milliyetler politikası iyi ama sınıf savaşımını göz ardı eder vaziyettedir. Çünkü köydeki halk arasında herhangi bir ayrım yapılmamıştır ve köylerde Sovyet güçlerinin ne ile savaştı̆̆ı bilinmemektedir. -Esenenko, orta sinıf köylü-

Tüm halk Basmacı, bu yüzden yaşı her ne olursa olsun tüm halkı ortadan kaldırmalıyız. -Budin, fakir bir köylü $55 \%$.

Buraya kadarki bilgilerden ve verilen örneklerden görüldüğü gibi, Basmacılara bölge halkının büyük bir desteği söz konusudur. Bununla birlikte, Basmacıların Sovyet yetkililerine ihbar edildiği durumlar da meydana gelmiştir. 20 Haziran 1924 tarihinde Frunze'ye gönderilen bir raporda böyle bir hadise sonrası, Basmacıların, kendilerini ihbar edenleri kaynar kazana attıkları bilgisi verilmiştir ${ }^{56}$.

Basmacı hareketini ele alan çalışmalarda en çok tartışlan hususlardan biri de dış güçler meselesidir. Nitekim bilhassa Sovyet kaynaklarında hareketin dış güçler tarafından desteklendiğine vurgu yapılmıştır. Özellikle Afgan yönetiminin bu süreçte Basmacı liderlerine büyük destek verdiği bilinmektedir. Bazı Sovyet arşiv belgelerinde de bu konuya dikkat çekildiğini görüyoruz. 20 Haziran 1924 tarihinde SSCB Askeri Devrim Konseyi Başkan Yardımcısı Frunze’ye Askeri Devrim Konseyi üyelerinden Berzin’in yazmış olduğu raporda Basmacılara Afgan yönetiminin destek verdiğine dikkat çekilmiştir:

"Gizli servisin verilerine göre, Kabil'de (Tacikistan) Buhara Emiri'nin temsilcileri ile Basmaci temsilcilerinin katılımıla bir toplantı organize edilmişti ve bildirildiğine göre Afgan hükümeti de bu toplantıya katılanlar arasındaydı. Toplantıda, terörün nihai ve kesin bir tedbir olarak kullanılmasına karar verildi. Emir ajanları bu kararı uygulamak için Buhara'ya gönderildi. Eğer terör arzu edilir sonuçlar verirse, o taktirde Emir, Basmacı hareketine gereken maddi desteği verecekti. Ayrıca Basmacılar için

Buhara'ya tüfek ve mühimmat gönderildiğine dair de malumatlar var ${ }^{57 \%}$.

Sovyet yönetiminin Basmacı hareketini bastırmak konusunda ne kadar zorlandığı, bu süreçte Müslüman din adamları sınıfından da istifade edilmesinden

55 RGVA,f. 25895,op.2,d.20,1.46.

56 RGVA,f.110,op.1,d.205,1.137.

57 RGVA,f.110,op.1,d.205,1.137.

Belleten, Nisan 2021, Gilt: 85/Say1: 302; 279-309 
anlaşılabilmektedir. Bu politikanın en açık örneği, Buhara Halk Cumhuriyeti Ulema Kurultayı'nın 1924 yılında Basmacılar hakkında yapmış olduğu şu çağrıdır:

"Buhara Halk Cumhuriyeti'nin her vilayetinden yüzden fazla kişi daha net ve doğru bir şekilde Basmacı tartışmak için toplandık. Son üç yıldır bu kötü durum devam ediyor, kan dökülüyor, ekonomi zarar görüyor. Basmacıların esas amacı, şeriat ve gerçek inancın örtüsü altına saklanmaktır. Bu, ikiyüzlülük ve aldatmacadır. Basmacıların faaliyetleri neye istinat ediyor. Kurultayda bunları biz şöyle sıraladık: Köylerdeki halkı yağmalayıp öldürmek, gençleri ve kadınları köylerinden zorla alıp götürmek, ... ailelerini doyurmak için köylerdeki çarşılara giden yoksul tüccarlara bile haraç kesmek ve soymak, ... Bizler ulema olarak bütün bunları kabul edilemez ve şeriata aykırı buluyoruz. Kuran'a göre, Basmacılar en ağır şekilde cezalandırılmalıdır, çünkü onlar, inancın yerine getirilmesinin ahlaklılıkla olacağını söyleyen Peygamber’in emirlerine aykırı bir şekilde davrandıklarından Allah'ın gözünde kafirdirler. Kuran şöyle der: İktidarı Allah bahşeder ve onu hakkedene bahşeder ${ }^{58}$ ".

Buhara Halk Cumhuriyeti Ulema Kurultayı'nda Basmacılıkla mücadele konusunda başka çok çarpıcı ifadeler de yer almıştır:

"1. Ülke ekonomisini soyup yok eden Basmacılar halk düşmanıdır. Basmacılar, soygunculuk amacıyla halkı kandırmak için İslam'ı koruma bahanesine sığınıyorlar. Ancak bu, Basmacıların şeytani bir aldatmacasıdır, Ulema Kurultayı bunu açı̆̆a çıkarıyor ve diyor ki: Basmacılar İslam'ın savunucuları değil düşmanıdırlar.

2. Basmacılar arasında, onları Buhara Emirliği'nin birer destekçisi haline dönüştürmeye çalışan Emirin memurları da yer alıyor. Bu nedenle Ulema Kurultayı, Emir'in ülkenin hükümdarı olamayacağını halka duyurur, çünkü yıllardır insanlar tarafindan şeriatı istismarla suçlanmaktadır. Sovyet rejimi, şeriatla ters düşmeyecektir; halkın iktidarını güvence altına alacaktır. $\mathrm{Bu}$ yüzden halkımız ona sadık olmalı ve mümkün olan tüm yardımı göstermelidir ${ }^{59}$ ".

Kurultay, ulemanın Basmacılara yaptığı şu çağrı ile son bulmuştur:

“... Bu yüzden Ulema kurultayı, sik sik Kur'an'a atıfta bulunuyor, Basmacıların Sovyet hükümeti tarafindan ilan edilen aftan istifade ederek teslim olmalarını ve barış dönemini başlatmalarını teklif ediyor. Buhara Sovyet yönetimi boş yere kan dökülmesini istemiyor. Sovyet yönetimi bu

58 RGVA,f.110,op.1,d.226,1.31ob.

59 RGVA,f.110,op.1,d.226,1.32. 
yüzden, Basmacıların güvenle barış içinde teslim olabilecekleri ve geçmişteki suçları yüzünden yargılanmayacakları çağrısında bulunuyor. Bizim tek bir arzumuz vardır: Halkın Basmacı belası ve endişesinden kurtarılması. Eğer Basmacılar tarafindan bu talep reddedilirse ve onlar, sivillere zarar vermeye devam ederlerse, o taktirde Basmacılara karşı en sert önlemler alınmalı ve tüm halk, Basmacıların nerede saklandıkları, silahlarının nerede olduğu konusunda Sovyet yönetimine yardımda bulunmalıdır. Bu, Basmacı hareketin erken bitişine, ülkemizin barış ve düzene kavuşmasına yardımcı olacaktır ${ }^{60 "}$.

Sovyet yönetiminin Basmacılıkla mücadele amacıyla uyguladığı bir diğer taktik, gayrı Rus milletlerden birlikler teşkil etmek olmuştur. Altmışova, Sovyetyönetiminin, Basmacı hareketinin ırksal/dinsel karakterini azaltmak için Müslümanlardan Kızıl Ordu birlikleri oluşturduğunu belirtmiştir ${ }^{61}$. Ancak Sovyet idarecilerinin bu süreçte bazı zorluklarla karşı karşıya kaldığı anlaşılmaktadır. 7 Temmuz 1931 tarihinde Askeri Devrim Konseyi üyelerinden Gryazov'un, orduların etnik yapısı hakkında Voroşilov'a sunduğu raporda şu bilgiler yer almıştır:

"Orta Asya Komünist Partisi Merkez Komitesi, tüm milletler için zorunlu askerlik kararı aldı. Bu karar yaklaşan Sovyet kongrelerinde uygulanacaktır. ... Ulusal dillerde kaleme alınmış yasa, yönetmelik ve askeri literatür eksikliği, bu milletlerin eğitim ve öğretim sürecinde büyük zorluklar yaratmaktadır. Bu problemi kendi başına ne Cumhuriyet ne de Bölge çözemez, bu süreçte merkezin yardımına ihtiyaç var. Ulusal askeri birliklerin yanı sıra bölgedeki tüm birliklerde milli gruplar çoğunluktalar. Öyle ki bir tümenin tamamı Tatar, Başkurt, Çuvaş, Mordov ve Vot birliklerinden oluşmaktadır. Bu durum tabi ki, onların gelişiminin daha düşük seviyede olması dolayısıyla büyük zorluklar yaratıyor. $\mathrm{Bu}$ milletlerden komutanlar mevcut değil. Hazırlıklar, çevirmenler aracılığıyla gerçekleştiriliyor. Birlik okullarında bu daha da büyük zorluk yaratıoor ${ }^{62}$ ".

Sovyet yönetiminin bir başka taktiği ise, göçebeleri iskân etme siyasetiydi. Bunun nedeni, Basmacıların sıklıkla göçebe halk arasına gizlenmeleriydi. SAVO Devrimci Askeri Komite üyelerinden Yastrebov'un, Askeri ve Deniz İşleri Halk Komiseri Voroşilov'a mektubunda göçebe unsurlar ve Basmacılıkla mücadele ilişkisi hakkında şu değerlendirmeler yer almıştır:

"Komünist Parti Merkez Komitesi Orta Asya Bürosu, Basmacı hareketinin tasfiyesi meselesini tartışırken, Orta Asya'daki Birleşmiş Devlet Siyasi İdaresi

60 RGVA,f.110,op.1,d.226,1.33ob.

61 Altmışova, agm., s.94.

62 RGVA,f. 25895,op.1,d.62,1.53ob.

Belleten, Nisan 2021, Gilt: 85/Say1: 302; 279-309 
(OGPU) Yetkili Temsilcisi yoldaş Matson, bölgedeki Devrimci Askeri Komite'den Hazar-ötesi bozkır bölgesindeki (Krasnovodsk-Kungrad-KızllArvat) çeteci unsurların, Kazak-göçebelerin ve hayvan yetiştiricilerinin tasfiyesi ve göçebelerin temel kısmının daimi ikamet ettikleri yere geri döndürülmesi konusunda önlem alınması amacıyla özel komuta altında ayrı bir askeri birliğin kurulmasını ısrarlı ve kesin bir şekilde talep etti.... Son zamanlarda, Kazakistan topraklarından Hazar-ötesi bozkırlarında göçebe Kazak nüfusunun daimî ikametgahından ayrıldıkları ve diğer bölgelere -çoğunlukla da güneye- göç ettikleri gözlemlenmektedir. Bu durum daha çok et ticaretinin bir neticesidir, ancak bu göçler çeteci propagandayı kuvvetlendirmektedir. İçerisinde çeteci unsurların da yer aldığı göçebelerin bir kısmı silahlıdır. Göçebe nüfus arasında Sovyet parti çalışmaları hiçbir şekilde mevcut değildir. Göçebelerin anti-Sovyet tutumları, feodal-akrabalık ilişkilerinin ve çeteci ajitasyonun sonucudur ${ }^{63}$ ".

Sovyet yönetiminin bir diğer mücadele taktiği, bölgeye Rusları yerleştirmek olmuştur. Buna karşılık Basmacıların da Rus köylülerini bölgeden göndermeye çalıştıkları anlaşılmaktadır. 1921 yılına ait bir belgede bu probleme dikkat çekilmiştir: "Badsk ve Pazar-Korgan bölgeleri hakkında alınan bilgiler şunlardır: Basmacılar, köylüleri yerlerinden etmek ve mallarını ele geçirmek yoluyla Rus köylerini tahrip etmek konusunda kati kararlar aldılar. Basmacılardan kaçan yaklaşık elli köylü aile Blagoveşensk ve Argansk köylerine geldiler. ... Durum kritik, ... Bu köylüleri kurtarmak için gerçek bir yardım gerekli ${ }^{64}$ ”.

Basmacılı̆̆ı ele alan çalışmalarda hareketin yenilgiyle sonuçlanmasında en belirleyici hususlardan biri olarak, tam teçhizatlı Sovyet ordusu karşısında Basmacıların modern silahlardan mahrum oluşu gösterilmektedir. Sovyet arşiv belgelerindeki askeri yazışmalarda bu hususu doğrulayan örnekler çoktur. Bunlardan biri, 14 Mayıs 1931 tarihli belgede karşımıza çıkmaktadır. Tacikistan Alayının Politik Birim Komutanına hitaben yapılan yazışmada Rus birliklerinin teçhizat üstünlüğünü gösteren şu bilgiler yer almaktadır:

“26 Nisan günü, 16.55’te ... Babadağ'daki Bor-Kutel geçidinde 80 kişiden oluşan Basmacı çetesi tespit edildi. Birliğimiz /tahminen 81 süvari alayı/ Tabu-Bulak bölgesindeydi. Yolda $(1.5 \mathrm{~km}$ doğuda) birliğimize çetenin nerede olduğu hakkında bir rapor ulaştı ve birlik Bor-Kutel geçidindeki Kara Kuz'dan yola çıktı. Birlik o yöne doğru ilerlerken, uçuş ekibi, çetenin dikkatini onlara yaklaşan birliklerden uzaklaştırmak için ateş açtı ve çetenin dağılmasına izin vermeden geçide sığınmak zorunda bıraktı. İlk müfreze

63 RGVA,f.25895,op.1,d.62,1.12.

64 RGVA,f.110,op.1,d.139,1.30. 
birliği ateş hattına yaklaştığında hava ekipleri çatışma mahaline yardım birlikleri çağırmak üzere hızlıca Stalinabad'a geri döndü. 19.10'dan 19.40’a kadar Skvirsk'in hava birlikleri Mitrofanov'un pilotları, çeteyi bombaladı. Başarılı bombalama ve silahlı hücum hareketiyle çete demoralize edildi ${ }^{65}$ ".

Bilhassa hava desteğinin Basmacılar karşısında Rus birliklerinin elini güçlendirdiği görülmektedir. Nitekim yukarıdaki belgeden bir gün sonrasına -15 Mayıs 1931tarihlenen bir başka belgede, yine hava destekli Rus birlikleri karşısında Basmacı birliklerinin çaresiz kaldığını görmekteyiz:

"3 Mayıs günü 40. Hava birliği pilotu Yoldaş Kolokolov, aynı birlikteki hava gözlem pilotu Kloçkov'la 10.40'ta birliklerimizin 300 süvariden oluşan bir çeteyle kuşatıldığı Agatı-Çaglı'da (Агаты-Чаглы) keşif uçuşu yaptı. Birliklerimizin zor durumda olduğunu gören hava ekibi, birliklere yardımcı olmak için saldırı düzenlemeye karar verdi. Pilotlar tarafindan makineli silahlarla ateşe tutulan çeteler, şaşkınlığa uğradı ve geçide sığındılar, böylelikle birliğimiz kuşatmadan kurtuldu. Uçaklarla desteklenen birlikler saldırıya geçti. Süvari birliklerinin yakınında bulunan flama, aynı hava ekipleri tarafindan düşürüldü. Bundan sonra, çete nihayet demoralize edildi ve 80 kişiye varan kayıplarla dağıldı ${ }^{66}$ ".

Sovyet ordusunun Basmacı birliklere karşı teçhizat üstünlüğü öyle bir boyuttaydı ki, onlara karşı kimyasal silah kullanımının gerekli olup olmadığı, tartışma konusu olmuştu. 1926 yılında Türkistan Cephesi Hava Kuvvetleri Komutanı Afanasyev'in, Türkistan Cephesi Komutanlığı'na sunduğu raporda ağırlıklı olarak atlı ve küçük gruplar halinde faaliyet gösteren Basmacı birliklerine karşı kimyasal silah kullanımının tamamen gereksiz olduğunu ve bunun hava bombalarının boş yere kullanılması demek olduğunu ifade etmiştir ${ }^{67}$. Buna karşılık Basmacıların hava desteği, kimyasal silah kullanımı gibi imkanlardan mahrum olması bir yana silah ihtiyacını büyük ölçüde Sovyet ordusundan elde ettiği ganimetlerle karşıladığı görülmektedir. Örneğin, 17 Ağustos 1921 tarihli bir belgede, Fergana'da Korbaşı Yuldan'ın Özkent'teki polis birimine düzenlediği saldırıda 22 adet tüfek ve 500 mermi ele geçirdiği bilgisi yer almaktadır ${ }^{68}$. Sovyet ordusunun teçhizat üstünlüğünü ortaya koymak açısından 1926 yılında Tacikistan’da yaşanan bir hadise de önemlidir. Türkistan Cephesi komutanlarından Kondrayev'in Türkistan Cephesi Komutanlığına ilettiği raporda hadiseyi şöyle aktarmaktadır: "Basmacılar

\footnotetext{
65 RGVA,f.25895,op.1,d.405,1.37

66 RGVA,f.25895,op.1,d.405,1.39.

67 RGVA,f.110,op.7,d.29,1.1ob.

68 RGVA,f.110,op.1,d.139,1.39.
} 
artık havadan açılan makineli tüfek ateşinden korkmuyor ve bombardımanlarda kimi zaman derelere sığınıyor ya da kıyı köşeye kaçıyorlar. ... Bombardımandan sonra sıklıkla bombanın düştüğü yere meraklarından geri dönüyor, kraterleri ve bomba parçalarını inceliyorlar. ... ${ }^{69 "}$.

Bununla birlikte, Basmacı hareketin ilk yıllarında Sovyet ordusunda da birtakım eksikliklerin mevcuttu. Örneğin, yeterli sayıda üniforma olmadığından bazı Kızıl Ordu askerlerinin giysisi yoktu ve askerler arasında tifoya yakalananlar $\operatorname{vardi}^{70}$. Sovyet ordusunun ulaşım konusunda da kimi zaman problemler yaşadığ görülmektedir. 1931 yılına ait bir belgede, ulaşım alanında vaziyetin pek de iç açıcı olmadığı, gelen malların taşınması ve boşaltılması işini askerlerin kendilerinin yaptıkları, sivil ulaşımı bu iş için kullanmanın mümkün olmadığı, çünkü askeri birliklerin durakladıkları yerlerde motorlu taşıtın neredeyse hiç bulunmadığı, çünkü bu taşıtların önemli kısmının kolhoz ve sanayi inşasında kullanıldığı ifade edilmiştir $^{71}$. Bunun dışında ordu içerisinde disiplin konusunda da sıkıntıların mevcut olduğu anlaşılmaktadır. Sovyet ordusundaki rehavet durumunu ortaya koyan örneklerden biri, 27 Mayıs 1921 tarihinde Andican'da Basmacılıkla mücadele hakkındaki bir raporda yer almaktadır:

“24 Mayıs’ta Andican’a geldik, Andican’ın durumu övünülecek gibi değil. Parti yok. İcra Komitesi Başkanı dışında kayda değer bir çalışan bulunmuyor. Sözde sorumlu kişiler arasında tanınmış Türkistanlı itibarlı kişiler var. ... Bugün ilginç bir olay oldu. Starıygorod İcra Komitesi Başkanı, Çeka'ya gizli bir paket gönderdi. Burada Starıygorod'a Basmacıların geldikleri, bir çayhanede durdukları ve halktan haraç ve para toplama emrini vermek üzere 50 kişiyi çağırdıkları yazıyordu. Bu ihbarı aldıktan sonra hemen Çeka'dan 15 kişilik bir birlik hazırladık ve karargâha gittik ne komutan ne de bir başkası yoktu. İki saat bekledik. Randevu alamadık. Telefonla karargâh komutanını aradık. Komutan geldi. Ona durumu açıkladık, ancak hiçbir şey yapmadı. Starıygorod'ta Müslüman birlikler ve garnizon, karargâhtan haber bekliyor. Her şey hazır, ama komutanlık çok yavaş hareket ediyor. ... Starıggorod'tan Basmacıların harekete geçtiği haberleri geliyor. Daha fazla bekleyemedik ve 30 kişilik bir grupla Basmacıları takip ettik. Yolda, hazır bekleyen 100 kişilik Müslüman birliğiyle karşılaştık, onlara bizimle birlikte hücuma geçmelerini teklif ettik, ama onlar, karargâhın bilgisi olmadan hiçbir yere gidemeyeceklerini söyleyerek bunu reddetti. ... Şehirde ayrıca süvariler de vardı, ama nerede olduklarını bilmiyorduk. Çeka birlikleri

69 RGVA,f.110,op.7,d.29,1.4-5.

70 RGVA,f.110,op.1,d.139,1.17ob.

71 RGVA,f.25895,op.1,d.62,1.55. 
ve 15 kişiyle kararlaştırdığımız yere vardık. Basmacılar aslında şehirden 3 mil ötedeydiler. Kendileri için hazırlanan çorbayı içtiler, birinden iki tüfek aldılar ve kaçtılar. Onları takip etmemiz tabii ki mümkün değildi, bu yüzden süvari birlikler bulmak için karargâha döndük. Her şey bittiğinde 30 kişiden oluşan bir atlı müfrezeyi bulup gönderdik. Toplantı için karargâha gittik. Karargâhta komutan yoktu, bu yüzden toplantıyı kabine açtı. 15 dakika devam etti. Sonra anlaşıldı ki Bay komutan eve dinlenmeye gitmiş ve akşam saat 7 'te gelecekmiş. Yani 4 saat sonra. ... Tüm bunlar Andican için sıradan olaylar... ${ }^{72 \%}$.

Orta Asya'daki Kızıl Ordu birliklerinin durumuyla ilgili bir diğer belge, "Orta Asya Askeri Devrim Konseyi Üyesi Gryaznov'dan Halk Komiseri K. Voroşilov'a Orduların Durumu Hakkında Rapor (orduların etnik yapısı hakkında)" başlıklı ve 07.02.1931 tarihli belgedir:

"Saygıdeğer Klementiy Efremoviç, emriniz doğrultusunda, bir aydan fazla bir süredir, Orta Asya Askeri Bölgesi'nde bulunmakta ve burayı geçici süreliğine idare etmekteyim. 1 tümeni, 1 Türkmen birliğini ve 8 süvari birliğini ziyaret ettim, bölgedeki tüm üst düzey askeri birliklerle büyük bir operasyonel çalışma yürüttüm, Semerkand'ta dă̆ ve kış şartlarında bir tatbikat gerçekleştirdim ve ziyaret ettiğim garnizonlarda birliklerin çalışmalarını izledim. Böylelikle, şimdiye kadar, bölgenin yüksek ve üst düzey komutasına ve onların hazırlık durumuna yeterince vakıf oldum. Mevcut durumu sizler için özetlememe izin veriniz. Askeri Devrim Konseyi'nin Ekim toplantısından sonra bölge toplantısı yapıldı. $\mathrm{Bu}$ toplantıda, bu sene için ortaya konulan hedeflerle uyumlu şekilde hazırlık talimatları ve problemler sert ve kararlı şekilde masaya yatırıldı. Bununla birlikte, 080 numaralı 1931 tarihli kararınızda talep ettiğiniz savaş hazırlıklarının hızlı şekilde uygulanması ve hayata geçirilmesinde en önemli hedefe henüz ulaşlamamıştır. Emir teoride tüm birliklerde yerine getirildi, fakat savaş sanayinin kurulması ve 080 numaralı karardaki talimatların yerine getirilmesi pratikte henüz tamamlanmadı. Askeri birlikler, savaş eğitimi çalışmalarını yeterince yoğun olmayan bir tempoda yürütüyorlar. Bölgenin komutasının önemli bir kısmının 80 numaralı kararın önemini henüz yeterince kavramadıkları anlaşılmaktadır. $\mathrm{Bu}$ nedenle, komuta kademesinde emrin yerine getirilmesine yönelik çalışmalara rağmen, şimdiye kadar çalışma metotları ve çalışmanın hızının artırılmasına yönelik bir şuur yeterince gelişmemiştir. ... Rasyonalleştirme talepleri, komuta kademesinde sadece serbest günlerin tanınmasından ibaret gibi algllanmıştır. Tüm savaş hazırlıklarının kalitesinin arttırılması konusunda olduğu gibi, çalışma günlerinin sıklaştırılması, gücün doğru düzenlenmesi, verimliliğin arttırılması, savrukluk ve zaman israfiyla mücadele gibi konularda da 
pratikte istenilen seviyeye ulaşılamamıştır. ... Bölge ordularının askeri hazırlıklarındaki duraklamadan ilk olarak şu tespit ediliyor ki, tüm komuta kademesinde teknik eğitim en yüksek kademede bile zayıftır. Bunun durum, askeri birliklerin Basmacılıkla mücadele çalışmalarından izole edilmesinden ve Basmacılıkla mücadelenin ilk aşamalarından beri, Orta Asya'daki teknik uzlaşmazlıklar konusunda komuta kademesinde mevcut olan indirgemeci bakış açısından kaynaklanıyor. ... Bölgedeki birliklerde atış talimleri hala aşağı seviyededir. Komuta kademesinde ateşli araçların kullanımı yeterli düzeyde değildir. ... Askeri atış poligonu, özel eğitim için gerekli olan şehirlerdeki ve köylerdeki tatbikat alanları tamamıla yetersizdir, çalışmalarda hiçbir şekilde yüksek verimlilik elde edilememekte ve modern gereksinimler karşılanamamaktadır. Eğitim kampları da yeterli donanıma sahip değildir ve büyük bir yatırım gerekmektedir. ... Orta Asya Komünist Partisi Merkez Komitesi, tüm milletler için zorunlu askerlik kararı aldı. $\mathrm{Bu}$ karar yaklaşan Sovyet kongrelerinde uygulanacaktır. ... Ulusal dillerde kaleme alınmış yasa, yönetmelik ve askeri literatür eksikliği, bu milletlerin eğitim ve öğretim sürecinde büyük zorluklar yaratmaktadır. Bu problemi kendi başına ne Cumhuriyet ne de Bölge çözemez, bu süreçte merkezin yardımına ihtiyaç var. Ulusal askeri birliklerin yanı sıra Bölgedeki tüm birliklerde milli gruplar çoğunluktalar. Öyle ki bir tümenin tamamı Tatar, Başkurt, Çuvaş, Mordov birliklerinden oluşmaktadır. Bu durum tabi ki, onların gelişiminin daha düşük seviyede olması dolayısıyla büyük zorluklar yaratıyor. Bu milletlerden komutanlar mevcut değil. Hazırlıklar çevirmenler aracılığıyla gerçekleştiriliyor. Birlik okullarında bu daha da büyük zorluk yaratıyor. ... Sayıları yıldan yıla artmakta olan kıdemli komutanların ev ihtiyacı karşılanamamaktadır, bununla birlikte askeri birliklerdeki konut krizini daha da şiddetlenmektedir. 1929-30 yıllarında Orta Asya Askeri Devrim Konseyi'nde bir dizi işletme, komuta heyetine mobilya temini konusunda kayda değer önlemler aldı, bu bölgede hala giderilmesi gereken acil bir ihtiyaçlar var. ... Bölgede dinlenme yerleri ve sanatoryumlar da yok, zaten bunlar için gerekli malzemeler de mevcut değil. Bununla birlikte, bölgede en az bir dinlenme tesisine ihtiyaç var, çünkü buradaki iklim özelliklerinden dolayı personelin yıpranma durumu diğer yerlerden çok daha fazladır. ... Bölge karargahında askeri hazırlık amacıyla 6 savaş oyunu düzenlenecek. Mart ayında tümen, süvari birliği, komiserler ile tümen ve tugay komutanları, karargâh komutanları ve alay komutanları 15 günlük makineli tüfek ve teknik konuların ele alınacağı bölge toplantısına katılacak. Toplantının son 5 günü, silah imalathanelerinde küçük silahların incelenmesini içeren pratik çalışmalara ayrılacak. ... Savaş oyunlarının tamamlanmasından sonra, liderliğimdeki tüm katılımcılar, bölgedeki askeri birlikler için -özellikle gayrı Rus halklardan (Özbek, Tacik, Türkmen ve Kazak)- komutanların yetiştirildiği Lenin Orta Asya Askeri Okulu'ndaki savaş eğitimini teftişe gidecekler. ... Şubat ayı başlarında dağlık ve kışlık koşullarda mücadele deneyimi kazanmak amacıyla tatbikat düzenlendi. 
Ulaşım alanında vaziyet pek iç açıcı değil. Gelen malların taşınması ve boşaltılması işini ordular kendileri yapıyor. Sivil ulaşımı bu iş için kullanmak mümkün değil, çünkü askeri birliklerin durakladıkları yerlerde motorlu taşıt neredeyse yok, çünkü bu taşıtların kayda değer kısmı, kolhoz ve sanayi inşasında kullanılıyor. Ulaşım da neredeyse mümkün değil, çünkü dehkanların büyük kısmı hala malzemelerin at, eşek ve develerle taşındığı tekerlerli katarları kullanıyor. ... Sizden, at ve insan katarlarıyla yaşanabilecek olası bir talihsizliği önlemek amacıyla bölgede 4 kışla ve 4 ahır inşa etmek için hiç değilse 1.000.000 ruble tahsis etmenizi rica ediyorum. Genel olarak, dağ birliklerinin donanımı ciddi bir kontrol ve ciddi düzenleme gerektirir. Bölgede 387 adet eğerin eksik olması, doğrudan buradaki savaş hazırlığını sekteye uğratıyor. Sonuç olarak, Kızıl Ordu'nun siyasi ve moral durumunun temelde oldukça tatmin edici olduğunu, bununla birlikte savaş hazırlıklarının yüksek talep içerdiğini doğrulamak gerekir. Parti teşkilatı tamamen savaş çalışmaları için seferber edildi, burada temel bir eksiklik, Parti teşkilatının taleplerini yerine getirecek her dereceden komuta eksikliğidir, yönetim açısından büyük eksiklikler var.

Gryaznov ${ }^{73}$ "

Mücadele yıllarında Sovyet Kızıl Ordusu içerisindeki disiplinsizliklere bir diğer örnek, "1931 Yılında Orta Asya Kızıl Ordu Askerleri Arasındaki Gayrı Ahlaki Hadiseler Hakkında Haberler" başlığıyla yer almıştır. 1931 yılına ait olan bu belgede farklı milletlerden askerlerin birbirlerine yönelik hakaret içeren ifadelerine yer verilmiş ve bu durum, "Büyük Güç Şovenizmi” olarak tanımlanmıştır. Belgede Türkmen Ana Kuliyev'ın Kızıl Ordu askerlerine, onlara küfretmek suretiyle kaba bir şekilde davrandığı, 24/III bölüğündeki Abaimov'un, Tatar bir Kızıl Ordu askerini "Tatar surat" diye çă̆ırdığı, 4. bölükteki Kiyanenko'nun sahadaki taktik eğitim sırasında ăgacın altında duran bir Özbek askerine "Basmacı" diye hakaret ederek tüfeğiyle saldırdığı, Siyasi Komiser Polyanin’in Tatar bir Kızıl Ordu askerinin "neden bizi ders almaya göndermiyorsunuz?" sorusuna "Rus Kizıl Ordusuna Rus soyundan gelen askerler gerek" cevabını verdiği, Haziran ayında yemekhanedeki kahvaltı sirasında Kızıl Ordu askeri Fedotov'un, Yahudi Kızıl Ordu askeri Yagutkin'e "bu kaşık benim ve onu bana vereceksin" diye seslendiği ve kaşık kendisine verilmediğinde Fedotov'un onu zorla alarak kaşı̆̆ kırdığı ve Yagutkin'e "Yahudi surat" dediği şeklindeki açıklamalar yer almıştır". Belgedeki bu örnekler, farklı milletlerden müteşekkil Kızıl Ordu içerisindeki ayrışmaları açıkça ortaya koymaktadır.

73 RGVA, f.25895,op.1,d.62,1.50-56.

74 RGVA, f. 25895 ,op.2, d.26, 1.50.

Belleten, Nisan 2021, Gilt: 85/Say1: 302; 279-309 
Arşiv belgelerindeki bu bilgilere rağmen, Sovyet ordusunun askerî açıdan Basmacı birliklerinden çok daha fazla imkana sahip olduğu ortadadır. Buna rağmen, 1931 gibi geç bir tarihte bile, Sovyet ordusunun hareketi bastırmakta zorluk yaşadığını görüyoruz. Nitekim Basmacı hareketin sona yaklaştı̆̆ bir dönemde, Tacikistan'daki mücadele büyümeye devam etmiştir. 14 Mayıs 1931 tarihli arşiv belgesinde Tacikistan'daki vaziyet ile ilgili şu açıklamalar yer almıştır:

"Bu konuda ayrıntılı olarak burada konuşmayacağım, çünkü bu, Tacikistan'daki parti teşkilatlarının, Parti liderliğinin, Sovyet aparatı ve bu cumhuriyetteki ekonomik faaliyetlerin idaresinden sorumlu kişilerin çalışmalarıyla ilgilidir ve bu çok zaman alır. Sadece kısa bir şey söyleyeceğim, bölgedeki ekmek kıtlı̆̆ı ve üretim mallarından yoksunluk, tükenmişliğe ve açlıktan ölüme dek varan aşırı bir noktaya ulaştı. Bu nedenle, Kızıl Ordu birliklerini temelsiz bir şekilde suçlamamak adına, askeri operasyonlar değerlendirirken bütün bunlar dikkate alınmalıdır, çeteciliğin tasfiyesi konusunda sebat eksikliği olduğu açıktır. Tabii ki, bir dizi eksiklikler, korkaklığın tezahürü vb. vardır, ancak bunlar sadece bireysel istisnai durumlardır ve çok azdır, eşsiz kahramanca eylemler daha fazladır. Komutanlık, Kızıl ordu askerlerinin her türlü övgüye layık bir mücadele yürüttüklerini ve Kızl Ordu askerlerine herhangi bir suçlamada bulunulamayacağını ifade ediyor. Bununla birlikte, bazı GPU mensuplarının, birliklerin operasyonlarını kötülemek gibi anlaşılmaz bir eğilim içinde oldukları bilinmektedir ${ }^{75}$ ".

Görüldüğü gibi, Tacikistan'da Basmacılık hareketinin büyümesinden Kızıl Ordu değil bölgedeki idari aparat sorumlu tutulmakta ve GPU'nun Kızıl Ordu'yu suçlaması eleştirilmektedir. Nitekim 13 Temmuz 1931 tarihli bir başka belgede de Kızıl Ordu'nun kahramanca mücadelesine vurgu yapılmaktadır. SAVO üyelerinden Yan Gamarnik'a yazılan mektupta şu açıklamalar yer almaktadır:

"Saygıdeğer Yan Borisoviç

2 ay süresince bölgede, Afganistan'daki Basmacı liderinin ele geçirdiği Tacikistan ve Özbekistan'daki Basmacllık hareketini bastırmak amacıyla çok yoğun ve sıkıntılı bir mücadele yaşandı. İsgal anında Tacikistan'daki durum son derece ağırd, Merkez Komitesi ve hükümetin ifadesine göre, genel bir ayaklanma an meselesiydi. Büyük bir ekonomik ve siyasi gerilik, feodalkabile ilişkileri, kulakların, ruhani ve bürokratik unsurların mevcudiyeti söz konusuydu. Ürünlerin ve tahılların ikmalinde büyük sskıntılar yaşanıyordu. Aşırı güçsüzlük, tıkanmışlı mevcuttu ve yerel Sovyet yönetiminin sık sık bize düşmanca yaklaşımı, açık bir şekilde Basmacılara sempatisi söz konusuydu ve daha da ötesinde Basmacılar için çalışıyorlardı. ... Tacikistan GPU'nun

75 RGVA,f.25895,op.1,d.62,1.20ob.

Belleten, Nisan 2021, Cilt: 85/Sayı: 302; 279-309 
yöneticisi Tacikistan'daki durumu şöyle izah ediyordu: "İbrahim Bek geldiği sırada buradaki vaziyet korkunçtu. Size, Muminabad ve Langar'daki savaş dönemine dair bir örnek vereyim. Birkaç istisna dışında halkın tamamı bize muhalifti. ... Molla Şerif'le yaşanan savaşta onların 150 askerine karşılık bizim asker sayımız 80'di. Muharebe mevkii, Basmacıları içtenlikle destekleyen binlerce dehkanla (Orta Asyalı köylüler) kuşatılmıştı. Bir Basmacı savaş alanından kaçmaya kalktığında dehkanlar onları derhal tutukluyor ve geri gitmeleri için ateş açıyor ve yaralıları öldürüyorlardı.” ... Savaş şartları son derece zor ve karmaşıtı. Dağlık ortamda çalışmanın zorluğu, göçebe ve hızlı Basmacı çetelerle sürekli bir mücadele, ordunun gerçekten kahramanca bir mücadele yürütmesini gerektiriyordu. ... Operasyon 2 ay gibi kısa bir sürede, Basmacıların tam bir bozgunu ve imhasıla tamamlandı. Basmacı hareketi yenilgiye uğradı. Tacikistan mücadeleden daha güçlü çıktı ve tamamen yeni bir yüze kavuş̧tu. Bu yenilenme ve yükselişte özellikle Kızıl Ordu önemli rol oynadı. Askerler, kumandanlar ve siyasi komiserler, kitlelerin gerçek organizatörleriydiler. Bir tek Basmacı dahi sınırı geçemedi. İbrahim Bek’in tüm ekibi yakalandı. 10 yıl boyunca bizimle başarılı bir şekilde savaşan Orta Asya'nın efsanevi kişiliği Ibrahim Bek’in kendisi de yakaland $1^{76}$ ".

Bu belgede dikkat çekici olan bir başka husus, Basmacı liderlerinden İbrahim Bek’in hareket içindeki rolünün Sovyet tarafinca da taktir edilmekte oluşudur. Nitekim belgede kendisinden "Orta Asya'nın efsanevi kişiliği” olarak bahsedilmiştir. İbrahim Bek’in yerli halk tarafindan nasıl mitleştirilmiş olduğu da yine bir arşiv belgesinde şu sözlerle dile getirilmiştir: "Bazı gayri Rus birliklerde İbrahim Bek’in yenilmez olduğu gibi bir inanış söz konusu, kendisi tıpkı bir evliya gibi görülüyor. İbrahim Bek sözde her savaştan sonra gömleğini silkeliyor ve içinden dolu mermiler dökülüyormuş. Kızıl Ordu ile ortaklaşa çalışmalardaki eksikliğin bir sonucu olarak bu birliklerde batıl inanışlar gözlemleniyor"77. Bilindiği gibi, İbrahim Bek, 1920'li yılların ikinci yarısından itibaren Doğu Buhara'daki Basmacı hareketine liderlik etmiş önemli bir isimdir. Bu sebeple olsa gerek, İbrahim Bek’in Afganistan'a kaçışı Sovyet tarafinda büyük bir infiale sebep olmuştur. Bilindiği gibi, en başından itibaren, Afganistan’ın Basmacı hareketine önemli bir desteği söz konusuydu. Bu konuda Bademci, 1920 yılında Afganistan’ın başına geçen Amanulah Han’ın, ülkedeki Türklerden gördüğü yardımlar ve ayrıca aynı dine mensup olmanın şuuruyla hareket ederek Basmacılara destek verdiğini ifade etmiştir. Bademci, korbaşılar heyetinin 31 Ağustos 1920 tarihinde Amanullah Han ile Kabil'de görüşü̆günü, Amanullah Han ve Harbiye Nazırı Nadir Şah’ın onları

76 RGVA,f.25895,op.1,d.62,1.37, 37ob.

77 RGVA,f.25895,op.1,d.405,1.7.

Belleten, Nisan 2021, Cilt: 85/Sayı: 302; 279-309 
ilgiyle karşıladıklarını ve burada onlara cephane yardımının yanı sıra Basmacı hareketin madden ve manen destekleneceği sözünü verdiklerini söylemiş̧iir ${ }^{78}$. Afganistan yönetimi bu sözünü tutmuş ve mücadelenin en kritik zamanlarında da bu yardımlarını sürdürmüştür. İbrahim Bek'in Afganistan'a kaçışının Sovyet nezdinde nasıl bir kargaşaya sebep olduğunu yine bir arşiv belgesinden öğreniyoruz:

“İbrahim Bek'in geçişi sırasında, GPU hala Tacikistan'a askerlerin gecikmeli transferi nedeniyle Bölge Komutanlı̆̆ını suçluyor. ... İbrahim sınır geçişi esnasında sını birlikleri onun geçit yerini keşfedemedi ve onlarla hiçbir mücadele yaşanmadı. Bizim şu ana kadar ki verilerimize göre, İbrahim Bek'in çetelerinin çok önemli bir kısmı yok edildi. Yaklaşık 30 kadar Korbaşı öldürüldü ve yaralandi; ancak bu süre zarfinda çeteler azalmadı, aksine daha da arttı. Eğer geçiş sırasında 900 ila 1.200 çete vardıssa, şu anda 2100-2300 kadar çete mevcut. Şu anda, bazen tüm kolhozun ve kolhoz çalışanlarının da katıldığı bir dizi yeni çete ortaya çıktı ${ }^{79}$ ".

Bu belgedeki açıklamalardan, İbrahim Bek'in Afganistan'a kaçışı konusunda GPU'nun, Bölge Komutanlığı’nın ihmali olduğunu düşündüğü anlaşılmaktadır. 26 Haziran 1931 tarihli belgede, İbrahim Bek'in kaçısıılla ilgili bu suçlamalar hususunda, SAVO’nun, Askeri ve Deniz İşleri Halk Komiseri ve Devrimci Askeri Komite Başkanı Klementiy Yefremoviç Voroşilov'a hitaben yaptığı şu savunma yer almaktadır:

Tekrar ediyorum, Orta Asya Askeri Devrim Konseyi'nin daha az kalıcı bir mücadele yürüttüğü doğrudur ve kendisine yöneltilen suçlamaları cesurca kabul etmiştir, İbrahim Bek'in kaçış hadisesine dek herhangi bir bahaneye ve suçlamalara firsat vermemiştir. Ordu komutanları uyarılara rağmen geciktiler, orduyu sınıra zamanında göndermediler, İbrahim Bek'in geçişi konusunda ikazda bulunmadılar, sözde Sovyet cumhuriyetlerinden birini ayaklanma tehlikesi ile karşı karşıya bıraktılar ve savaş denizinde batırdılar. $\mathrm{Bu}$ teorinin saçmalığı, okuma-yazması olmayan ordu mensubu için bile ortadayken, yönetici çevrelerde bile destek gördü ve sıkça karşılaştığımız üzere, bu söylentiler Moskova'ya kadar taşındı. ... Dışarıdan Basmacılarla ilişkili büyük bir hareket meydana geldiğinde, 2 aylık bir süre içinde tüm hareket bastırıldı, parçalandı ve tamamen yok edildi. Bu mücadelenin koşulları ve olağanüstü zorlukları hakkında burada detaya girmeyeceğim, ben özellikle bu konudaki bazı bulguları size açıklamak istiyorum. Ancak GPU'nun uyardığı ve Askeri Devrim Konseyi'nin istilanın önlenmesi

78 Bademci, age., s. 283-284.

79 RGVA,f.25895,op.1,d.62,1.20-23 
için hiçbir önlem almadığına dair iddia, Konsey’i ciddi bir itham altında bırakmaktadır. ... İbrahim 5 yıl boyunca sınır bölgesinde bizimle yaşadı ve GPU sürekli olarak uyardı. Bölge komutanlığına katıldığım ilk gece tam anlamıyla böyle bir uyarı ve asker talebi yaşandı. Birliğe yeni katılmıştım, ancak bu durumun birkaç yıldır devam ettiğini öğrendim. Gözlerimin önünde üç ay boyunca, İbrahim sürekli yer değiştirdi ve çeşitli manevralar yaptı, 650 verste kadar sınır boyunca düz bir hatta tam sınırda dolaştı, GPU tabi ki her seferinde uyardı ve asker talep etti. Bir ikilemle karşı karşıya kaldım: bölgedeki tüm silahlı kuvvetleri sınıra hareket ettirmek (ki bu çok zor olurdu) ya da tüm öğrendiklerimi bir kenara birakarak, Bah’tan Kerkov'a kadar $(800 \mathrm{~km})$ tüm sınırı kapatmak, o taktirde beni cahil ve soğukkanlı olmamakla itham ederdiniz. ... ... Saldırılar sırasında SAVO'nun suçu ve uyarılar hakkındaki iddialar büyüdü ve Klamentiy Yefremoviç inanınız, bizim üzerimizde büyük bir baskı yarattı. Bizim bir suçumuz yoktu, ancak müttefik cumhuriyetlerden biri ağır bir yıkımla ve ciddi bir siyasi ve ekonomik tehditle karşı karşıya kaldı ${ }^{80}$ ".

\section{Sonuç}

Basmacı hareketin yenilgisinde kuşkusuz Sovyet birlikleri ile kıyaslandığında askeri teçhizat konusundaki eksikliğinin büyük payı vardı. Bu noktada Basmacı hareketi konu alan hemen tüm kaynaklarda bir fikir birliği söz konusudur. Çalışmada istifade edilen arşiv belgelerinde bu duruma delil teşkil edecek örneklere yer verilmiştir. Örneğin, Basmacıların silah konusundaki eksikliklerini büyük oranda Sovyet ordusundan ele geçirilen "ganimetlerle" tamamlaya çalışırken, buna karşılık Sovyet ordusunun hava desteğine sahip oluşu, durumun Basmacılar açısından vahametini açıkça ortaya koymaktadır. Sovyet ordusunun teçhizat konusundaki üstünlüğüne rağmen, Basmacı hareketin yenilgiye uğratılması hiç de kolay olmamıştır.

Basmacı direnişinde kuşkusuz en büyük pay, bölge halkının Basmacılara olan desteğiydi. Basmacı hareket özünde Türkistan'daki Müslüman yerli halkların mücadelesiydi. Bu nedenle silahlanarak faaliyete geçen Basmacı gruplar halktan çok fazla destek görmüşür. Pek çok bölgede orta halli ve fakir halkın direnişe katılması Basmacı sayısının artmasına sebep olmuştur. Hareketin halkın desteğini alarak güçlenmesi, gelişmesi ve devam etmesi Sovyet yönetimi için büyük bir sorun teşkil etmiştir. Sovyet yönetiminin hatalı politikaları da Basmacı harekete olan halk desteğinin artmasına katkıda bulunmuştur. Çalışmada arşiv örnekleri, Sovyet yönetiminin toprak reformunun yanı sıra bölgedeki Sovyet aparatının 
zayıf oluşunun ve ülke genelinde olduğu gibi burada da yoğun şekilde hissedilen ekonomik sıkıntıların Basmacılara olan halk desteğini arttırdığını göstermektedir. Ayrıca Bolşeviklerin, halkın gelenek ve inançlarına saygı göstermemesi, Sovyet hükümetinin vermiş olduğu ulusların kendi kaderini tayin edebileceği sözünü tutmaması ve halkın çıarlarını gözetmemesi gibi sebepler halkın Basmacı hareketini desteklemesinde etkili olmuştur.

Basmacı hareketi güçlü kılan bir diğer özellik ise, savaşçıların bölgeyi iyi tanımaları ve bu zor coğrafi koşullarda savaşmaya alıskıı olmalarıydı. Onların bölgeyi iyi tanımaları rahatlıkla gizlenebilmelerinde etkili olmuştur. Basmacılar zor koşullarda savaşmaya alışkın olsalar da onlar arasında asker eğitimi alan savaşçıların sayısı azdı. Ayrıca onların silahları da gelişmiş ve yeterli değildi. Ancak bu durum onların uzun yıllar mücadelelerine devam etmelerine engel olmadı. Basmacı askerlerin bir diğer özelliği de çok kez büyük darbe almalarına rağmen kısa zamanda toparlanıp silah buldukça mücadelelerini sürdürmelerindeki ısrarlarıydı. Onların bu ısrarı da direnişin devamında oldukça etkili olmuştur. 


\section{KAYNAKLAR}

\section{Arşiv Kaynakları}

\section{Rusya Devlet Askeri Arşiv (Rossiyskiy Gosudarstvennyy Voennyy Arkhiv)}

RGVA, f.110, op.1, d.139, 1.4-5ob.

RGVA, f.110, op.1, d.139, 1.14-14ob-15.

RGVA, f.110, op.1, d.139, 1.16ob, 17, 17ob.

RGVA,f. 110, op.1, d.139, 1.31.

RGVA, f.110, op.1, d.139, 1.39.

RGVA, f.110, op.1, d.205, 1.137.

RGVA, f.110, op.1, d.226, 1.31ob.

RGVA, f.110, op.1, d.226, 1.32.

RGVA, f.110, op.1, d.226, 1.33ob.

RGVA, f.110, op.7, d.29, 1.1ob.

RGVA, f.110, op.7, d.29, 1.4-5.

RGVA, f.25895, op.1, d.62, 1.20-20ob-23.

RGVA, f.25895, op.1, d.62, 1.23.

RGVA, f.25895, op.1, d.62, 1.30ob, 1.31.

RGVA, f. 25895, op.1, d.62, 1.37.

RGVA, f.25895, op.1, d.62, 1.37ob.

RGVA, f. 25895, op.1, d.62, 1.53ob.

RGVA, f.25895, op.1, d.62, 1.50-56.

RGVA, f.25895, op.1, d.405, 1.37

RGVA, f.25895, op.1, d.405, 1.39.

RGVA, f. 25895, op.1, d.405, 1.46-47.

RGVA, f. 25895, op.2, d.20, 1.46. 
RGVA, f.25895, op.2, d.26, 1.50 .

\section{Araştırma ve İnceleme Eserler}

Altımısova, Zuhra, "Kırgızistan'da Basmacı Hareketiyle İlgili Yeni Bilgiler (19251934)", Bilig, S. 82, Ankara 2017, s. 91-116.

Bademci, Ali, 1917-1934 Türkistan Milli İstiklal Hareketi, Korbaşllar ve Enver Paşa, Ötüken Neşriyat, İstanbul 2008

Donuk, Abdülkadir, "Basmacı Hareketi”, TDVA, C 5, İstanbul 1992, s.107-108.

Gutliyev, Gurbangeldi, “Türkistan'daki Basmacllk Hareketi (1918-1924) Üzerine Değerlendirmeler”, Anadolu Kültürel Araştırmalar Dergisi, S. 1 (2), 2017, s. 85-96.

Gümüs, Musa, "Türkistan'da Vatan Müdafaacıları: Korbaşılar Hareketi ve Enver Paşa", Tarih Okulu Dergisi, S. XXIV, 2015, s. 649-682.

Kurban, İklil, "Basmacılar", Selçuk Üniversitesi Türkiyat Araştrmalan Dergisi, S. 4, Konya 1997, s. 125-137.

Olcott, Martha, "The Basmachi or Freemen's Revolt in Turkestan 1918-24", Soviet Studies, C 33/S. 3, 1981, s. 352-369.

Penati, Beatrice, "The Reconquest of East Bukhara: The Struggle Against the Basmachi as a Prelude to Sovietization", Central Asian Survey, G 26/S. 4, s. 521-538.

Hayit, Baymirza, "Basmacılar": Türkistan Milli Mücadele Tarihi (1917-1934), Türkiye Diyanet Vakfi Yayınları, Ankara 1997.

Hayit, Baymirza, Türkistan Devletlerinin Milli Mücadeleleri Tarihi, Türk Tarih Kurumu Basımevi, Ankara 2004.

Yarımoğlu, Emin, Korbaşı Türkistan Milli İstiklal Hareketi Liderlerinden Şir Muhammed Bek, Bozkurt Yayınları, İstanbul 2019. 
